\title{
An offline correction method for uncompensated series resistance and capacitance artifacts from whole-cell patch clamp recordings of small cells
}

\author{
Cengiz Günay*, Astrid A Prinz \\ From Twentieth Annual Computational Neuroscience Meeting: CNS*2011 \\ Stockholm, Sweden. 23-28 July 2011
}

Whole-cell patch clamp recordings from small cells, such as in Drosophila, suffer from large series resistance (R_e) and capacitive artifacts $[1,3,4]$. While the series resistance error is caused by only the electrode, the capacitive artifact is caused by both the electrode and membrane capacitances. These artifacts cannot be compensated for with the standard amplifier circuits because of the feedback ringing and other instabilities caused by small cells.

Standard electrophysiological measurement procedures for determining ion channel parameters using the voltage-clamp protocol suffer the most from these artifacts because R_e affects the effective membrane voltage on the cell. For instance, a standard electrophysiological technique is to record multiple voltage protocols from multiple cells, average the traces from the same cells, and leak-subtract the average. This cell average trace is then normalized by the estimated capacitance of the cell and can be averaged across cells. During this procedure, an uncompensated R_e perturbs the expected outcome in two ways:

Within the same cell, R_e changes during the collection of multiple trials; usually increasing with time because of the cumulative clogging of the electrode tip.

Between cells, both electrode and seal leak parameters vary, which affect R_e and the leak that runs through it, both of which affect the membrane voltage, V_m.

We propose a simple and straightforward method and a publicly available Matlab implementation to address both of these problems. We use a standard model of electrode resistance and capacitance [2] together with

* Correspondence: cqunay@emory.edu

Dept. Biology, Emory University, Atlanta, Georgia 30322, USA an isopotential neuron model to simulate passive responses during recordings.

For each recording, we use voltage clamp steps that exhibit passive responses from the cell to fit the passive parameters of our passive model. This allows estimating passive parameters for each trial and independent subtraction of the artifacts. The success of this method is dependent on having access to non-leak subtracted recordings as otherwise $R_{-}$e and its effects cannot be estimated. Using this method, we estimated errors from two different voltage clamp datasets. One surprising result was that variable R_e contributes more significantly than the variable capacitance, such that capacitance normalization fails to regularize responses. In summary, we propose this offline series resistance estimation and removal method to complement voltageclamp experiments and to reduce errors during data analysis procedures.

\section{Acknowledgements}

Career Award at the Scientific Interface (CASI) from the Burroughs Wellcome Fund awarded to AAP. Experimental data was graciously provided by Dr.

Richard Baines at University of Manchester, Manchester, U.K., and Dr. Richard Levine at Arizona University, AZ, U.S.A.

Published: 18 July 2011

\section{References}

1. Duch C, Vonhoff F, Ryglewski S: Dendrite Elongation and Dendritic Branching Are Affected Separately by Different Forms of Intrinsic Motoneuron Excitability. J. Neurophysiol 2008, 100(5):2525-2536.

2. Preyer AJ, Butera RJ: Causes of Transient Instabilities in the Dynamic Clamp. IEEE Trans. Neural Syst. Rehabil. Eng 2009, 17(2):190-198.

3. Wolfram V, Pym E, Southall T, Brand A, Baines R: Acquisition of electrical properties in motoneurons is specified by a combinatorial code of transcription factors. J Neurogenetics 2009, 23:S62-S62, Meeting Abstract: VI59. 
4. Worrell JW, Levine RB: Characterization of voltage-dependent Ca2+ currents in identified Drosophila motoneurons in situ. J. Neurophysiol 2008, 100(2):868-878

doi:10.1186/1471-2202-12-S1-P259

Cite this article as: Günay and Prinz: An offline correction method for uncompensated series resistance and capacitance artifacts from wholecell patch clamp recordings of small cells. BMC Neuroscience 201112 (Suppl 1):P259.

Submit your next manuscript to BioMed Central and take full advantage of:

- Convenient online submission

- Thorough peer review

- No space constraints or color figure charges

- Immediate publication on acceptance

- Inclusion in PubMed, CAS, Scopus and Google Scholar

- Research which is freely available for redistribution

Submit your manuscript at www.biomedcentral.com/submit 